\title{
PENGARUH KUALITAS PELAYANAN DAN KEPUASAN TERHADAP NIAT BERKUNJUNG KEMBALI WISATAWAN MANCANEGARA KE DAYA TARIK WISATA ALAS PALA SANGEH
}

\author{
I Gede Noviana Putra \\ I Nyoman Sudiarta \\ I GPB. Sasrawan Mananda \\ Email : denaobenk@gmail.com \\ PS. S1 Industri Perjalanan Wisata \\ Fakultas Pariwisata UNUD
}

\begin{abstract}
ABSTRAK
Penelitian ini bertujuan membahas seberapa besar kualitas pelayanan dan kepuasan wisatawan mempengaruhi niat berkunjung kembali wisatawan mancanegara ke Daya Tarik Wisata Alas Pala Sangeh. Daya tarik wisata ini mempunyai sesuatu yang unik dibandingkan dengan daya tarik sejenis, yaitu penempatan ranger (pemandu lokal) yang senantiasa akan menemani dalam melakukan perjalanan disekitar areal daya tarik wisata ini, ranger (pemandu lokal) senantiasa memberikan kualitas pelayanan sesuai dengan standar prosedur.

Metode penelitian dalam pengambilan sample dilakukan menggunakan teknik Purposive Sampling, penyebaran sampel menggunakan Accidental Sampling dengan menyebar 100 kuesioner kepada wisatawan yang sedang melakukan kunjungan ke Daya Tarik Wisata Alas Pala Sangeh dan dengan 22 indikator pertanyaan yang telah disesuaikan. Dalam Analisis data menggunakan analisis deskriptif kuantitatif, analisis pengujian instrument penelitian, analisis regresi berganda, dan analisis korelasi.

Hasil akhir dalam penelitian, (1) Kualitas pelayanan berpengaruh positif dan signifikan terhadap niat berkunjung kembali wisatawan, (2) Kepuasan berpengaruh positif dan signifikan terhadap niat berkunjung kembali wisatawan, (3) Kualitas pelayanan dan kepuasan berpengaruh positif dan signifikan terhadap niat berkunjung kembali wisatawan secara simultan atau bersama-sama dan memiliki hubungan yang kuat. Adapun saran yang dapat disampaikan yaitu pengelola perlu meningkatan fasilitas toilet, peningkatan penanganan keluhan serta semakin giat mengikuti perkembangan pariwisata.
\end{abstract}

Kata Kunci : Kualitas Pelayanan, Kepuasan dan Niat Berkunjung Kembali.

\section{PENDAHULUAN}

Pulau Bali merupakan pulau kecil yang dikenal dengan sebutan Pulau Dewata, dan sudah terkenal sampai ke mancanegara. Pulau Bali yang juga dikenal dengan sebutan Pulau Seribu Pura sangat mendukung dan mengembangkan pariwisata sebagai sektor utama. Potensi utama yang menjadi daya tarik bagi wisatawan mancanegara maupun domestik adalah kekayaan adat istiadat yang begitu kental serta ditopang dengan keindahan alam yang masih terjaga.
Berdasarkan data kunjungan wisatawan mancanegara ke Bali pada tahun 2010 - 2014 yang didapat dari Dinas Pariwisata Provinsi Bali menunjukkan bahwa, kunjungan wisatawan mancanegara yang datang ke bali setiap tahunnya mengalami peningkatan presentase sekitar $11,11 \%$. 
Tabel 1. Jumlah Kunjungan Wisatawan Mancanegara ke Bali Tahun 2010 - 2014

\begin{tabular}{ccc}
\hline Tahun & Jumlah Wisatawan & Pertumbuhan \\
\hline 2010 & 2.493 .058 & 11,80 \\
\hline 2011 & 2.756 .579 & 10,57 \\
\hline 2012 & 2.892 .019 & 4,91 \\
\hline 2013 & 2.892 .019 & 13,37 \\
\hline 2014 & 3.766 .638 & 14,89 \\
\hline Jumlah & $\mathbf{1 5 . 1 8 7 . 8 9 2}$ & $\mathbf{5 5 . 5 6}$ \\
\hline Rata-Rata & $\mathbf{3 . 0 3 7 . 5 7 8}$ & $\mathbf{1 1 , 1 1}$ \\
\hline \multicolumn{2}{l}{ Sumber: Dinas Pariwisata Provinsi Bali 2015}
\end{tabular}

Banyak strategi dan pembenahan yang dilakukan pemerintah secara serius untuk menarik wisatawan dan mempertahankan kunjungan wisatawan mancanegara.

Kabupaten Badung merupakan salah satu merupakan salah satu kabupaten yang ada di Bali yang banyak melakukan pembenahan. Selain Pantai Kuta dan Nusa Dua yang menjadi daya tarik di Kabupaten Badung, ada sebuah tempat yang menyimpan nilai sejarah dan keasrian alam yaitu Daya Tarik Wisata Alas Pala Sangeh.

Daya Tarik Wisata Alas Pala Sangeh merupakan salah satu daya tarik wisata yang terkenal di Kabupaten Badung. Daya tarik wisata ini sempat menjadi sepuluh besar daya tarik yang selalu dikunjungi oleh Wisatawan Macanegara di Kabupaten Badung..

Penempatan ranger (pemandu lokal) untuk senantiasa menemani selama melakukan perjalanan disekitar areal daya tarik ini menjadikan sebuah nilai tambah bagi daya tarik ini. Adat yang masih kental di masyarakat Desa Sangeh serta keunikan dan kenakalan kera ekor abu yang ada di daya tarik wisata ini dapat menjadi sebuah pengalaman yang berbeda selama mengunjungi daya tarik wisata ini.

Berdasarkan data kunjungan wisatawan yang mengunjungi daya tarik wisata ini, selama lima tahun terakhir kunjungan wisatawan yang datang ke daya tarik wisata ini mengalami fluktuasi dan cenderung menurun. Rata-rata pertumbuhan wisatawan mancanegara yang datang ke sangeh selama lima tahun terakhir, kurang dari $1,24 \%$, dan sangat berbanding terbalik dengan kunjungan wisatawan mancanegara ke Bali yang semakin meningkat setiap tahunnya.
Tabel 2. Jumlah Kunjungan Wisatawan

Mancanegara ke Daya Tarik Wisata

Alas Pala Sangeh Tahun 2010 - 2014

\begin{tabular}{ccc}
\hline Tahun & Jumlah Wisatawan & Pertumbuhan \\
\hline 2010 & 20.221 & $-11,1$ \\
\hline 2011 & 14.871 & $-26,4$ \\
\hline 2012 & 12.568 & $-15,4$ \\
\hline 2013 & 15.617 & 24,2 \\
\hline 2014 & 19.137 & 22,5 \\
\hline Jumlah & $\mathbf{8 2 . 4 1 4}$ & $\mathbf{- 1 , 2 4}$ \\
\hline Rata-Rata & $\mathbf{1 6 . 4 8 2}$ & $\mathbf{1 1 , 1 1}$ \\
\hline
\end{tabular}

Sumber: Dinas Pariwisata Provinsi Bali 2015

Penelitian ini dilakukan untuk melihat kualitas pelayanan yang diberikan oleh ranger dan kepuasan yang diterima wisatawan apakah mempengaruhi niat berkunjung kembali wisatawan mancanegara ke Daya Tarik Wisata Alas Pala Sangeh.

\section{METODE PENELITIAN}

Identifikasi Variabel yang digunakan didalam penelitian ini adalah Variabel Bebas (Independent Varible) yang terdiri dari Kualitas Pelayanan (X1) dan Kepuasan (X2), serta Variabel Terikat (Dependent Variable) yaitu Niat Berkunjung Kembali (Y1)

Penelitian ini menggunakan dua jenis data yaitu kualitatif dan kuantitaif. Sumber data berupa data primer yang diperoleh langsung dari sumber data, yaitu melalui observasi dan wawancara dengan pihak pengelola terkait serta data sekunder yang dalam penelitian ini adalah data yang diperoleh secara tidak langsung dari objek penelitian, baik melalui membaca, memahami buku, literatur dan hasil penelitian sebelumnya yang berkaitan dengan penelitian ini.

Pada penelitian ini sample yang digunakan adalah wisatwan mancanegara yang berkunjung ke Daya Tarik Wisata Alas Pala Sangeh. Pengambilan Sampe dilakukan dengan teknik Purposive Sampling, yaitu menentukan sampel dengan beberapa pertimbangan tertentu, serta penyebaran kuesioner menggunakan metode Accidental Sampling

Jumlah sampel dalam penelitian ini adalah 100 orang Wisatawan Mancanegara, penentuan besarnya sampel dalam penelitian ini didasarkan pada pendapat Slovin (Husein Umar 2007)

Teknik analisis data dalam penelitian ini menggunakan teknik analisis kuantitatif, 
dengan pendekatan secara interaktif yang dapat dihitung dengan menggunakan alat bantu komputer yaitu program SPSS (Statistical Package for the Social Science) 17.00 for windows

Adapun tenik analisis data yang dapat dijabarkan adalah sebagai berikut :

1. Analisis Deskriptif Kuantitatif.

2. Analisis Pengujian Instrumen Penelitian.

3. Analisis Regresi.

4. Analisis Korelasi.

5. Analisis Koefisien Determinasi.

\section{HASIL DAN PEMBAHASAN}

Penelitian ini menggunakan 100 wisatawan mancanegara yang melakukan kunjungan ke Daya Tarik Wisata Alas Pala Sangeh sebagai responden. Berdasarkan data yang diperoleh dari 100 responden tersebut kemudian di analisis dengan bantuan program SPSS 17.00. Tahap pertama dilakukan Uji Validitas dan Reliabilitas, untuk melihat apakah data yang digunakan sudah mencakup dari data variabel yang diteliti secara tepat dan melihat seberapa konsisten jawaban yang diberikan terhadap pertanyaan yang diajukan. Seperti yang terlihat pada tabel 3 tentang Hasil Uji Validitas dan tabel 4 tentang Hasil Uji Reliabilitas.

\section{Uji Validitas}

Tabel 3. Nilai Validitas

\begin{tabular}{cllll}
\hline No & Variabel & Indikator & $\begin{array}{l}\text { Koefisien } \\
\text { Korelasi }\end{array}$ & Ket. \\
\hline 1 & Kualitas & X1.1 & 0,600 & Valid \\
& pelayanan & X1.2 & 0,572 & Valid \\
& (X1) & X1.3 & 0,601 & Valid \\
& & X1.4 & 0,407 & Valid \\
& & X1.5 & 0,607 & Valid \\
& & X1.6 & 0,483 & Valid \\
& & X1.7 & 0,535 & Valid \\
& & X1.8 & 0,734 & Valid \\
& & X1.9 & 0,683 & Valid \\
& & X1.10 & 0,517 & Valid \\
& & X1.11 & 0,699 & Valid \\
& & X1.12 & 0,518 & Valid \\
& & X1.13 & 0,513 & Valid \\
& & X1.14 & 0,519 & Valid \\
& & X1.15 & 0,367 & Valid \\
\hline 2 & Kepuasan & X2.1 & 0,426 & Valid \\
& (X2) & X2.2 & 0,611 & Valid \\
& & X2.3 & 0,554 & Valid \\
& & X2.4 & 0,443 & Valid \\
& & & & \\
\hline 3 & Niat & Y1.1 & 0,650 & Valid \\
\hline
\end{tabular}

\begin{tabular}{cccc}
\hline berkunjung & Y1.2 & 0,300 & Valid \\
kembali & Y1.3 & 0,699 & Valid \\
(X3) & \multicolumn{4}{l}{} \\
\multicolumn{5}{l}{ Sumber : Hasil pengolahan data penelitian 2015}
\end{tabular}

Hasil uji validitas pada tabel 3 menunjukkan bahwa semua variabel memiliki nilai koefisien korelasi sama dan diatas 0,3. Jadi instrument dapat dikatakan valid (Ghozali 2009).

\section{Uji Reliabilitas}

Tabel 4. Nilai Reliabilitas

\begin{tabular}{cllll}
\hline No & Variabel & $\begin{array}{l}\text { Cronbach's } \\
\text { Alpha }\end{array}$ & $\begin{array}{l}\text { N of } \\
\text { Item }\end{array}$ & Ket. \\
\hline 1 & $\begin{array}{l}\text { Kualitas } \\
\text { pelayanan } \\
\text { (X1) }\end{array}$ & 0,836 & 15 & Valid \\
\hline 2 & $\begin{array}{l}\text { Kepuasan } \\
\text { (X2) }\end{array}$ & 0,670 & 4 & Valid \\
\hline 3 & $\begin{array}{l}\text { Niat } \\
\text { berkunjung } \\
\text { kembali } \\
\text { (X3) }\end{array}$ & 0,680 & 3 & Valid \\
\hline Sumber : Hasil pengolahan data penelitian 2015
\end{tabular}

Dari hasil pengolahan data pada tabel 4 menunjukkan bahwa semua variabel dinyatakan valid karena memiliki cronbach's alpha diatas 0,6 .

\section{Hasil Analisis Regresi}

Analisis regresi linier berganda dalam penelitian ini bertujuan untuk melihat sejauh mana besarnya pengaruh kualitas pelayanan (X1) dan kepuasan (X2) terhadap variabel niat berkunjung kembali wisatawan (Y1) mancanegara yang mengujungi Daya Tarik Wisata Alas Pala Sangeh. Berikut adalah data hasil perhitungan analisis regresi linier berganda menggunakan program SPSS 17 for windows.

$\begin{array}{llcc}\mathrm{Y}=4,510+ & 0,192(\mathrm{X} 1) & +0,211(\mathrm{X} 2)+\mathrm{e} \\ \mathrm{SE}= & 0,023 & 0,069 \\ \mathrm{t}_{\text {hitung }}= & 8,247 & 3,064 \\ \mathrm{Sig}= & 0,000 & 0,000 \\ \text { Adjusted } \mathrm{R}^{2}= & 0,409 & \\ \mathrm{~F}_{\text {hitung }}= & 35,230\end{array}$

Dari persamaan tersebut dapat dijelaskan bahwa variabel kualitas pelayanan memberi nilai koefisien parameter sebesar 0,192 dengan tingkat signifikansi sebesar 0,000 dan variabel kepuasan memberikan nilai 
variabel koefisien parameter sebesar 0,211 dengan tingkat signifikansi sebesar 0,000 .

Dapat dilihat pada Gambar 1 yang menjelaskan bahwa pengaruh kualitas pelayanan dan kepuasan terhadap niat berkunjung kembali dengan nilai dari masing setiap variabel $\mathrm{X}$ terhadap $\mathrm{Y}$.

Gambar 1. Kerangka Hasil Penelitian

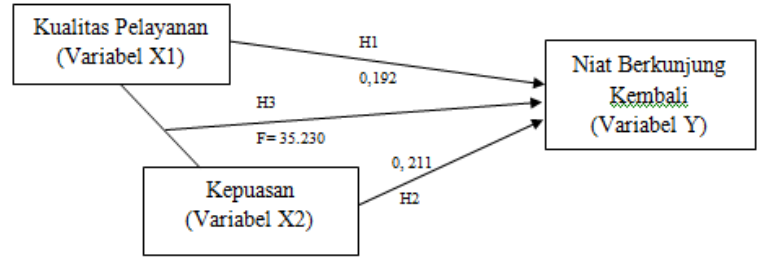

Sumber : Modifikasi dari Taviv Junaedi (2012), Festus and Maxwell (2006)

Pengujian hipotesis pertama dan kedua dilakukan menggunakan t-test (parsial) dengan tingkat signifikansi alpha 5\% terhadap loading factor. Pengujian ini dilakukan untuk menolak atau menerima Ho.

Seperti yang terlihat pada tabel 5 merupakan hasil dari penghitungan SPSS mengenai peujian hipotesis pertama, kedua dan ketiga.

Tabel 5. Hasil Uji Regresi Berganda

\begin{tabular}{|c|c|c|c|c|c|c|}
\hline \multirow{2}{*}{ Variabel } & \multirow[b]{2}{*}{ B } & \multicolumn{2}{|c|}{ Uji F } & \multicolumn{2}{|c|}{ Uji t } & \multirow{2}{*}{ Adjusted $\mathrm{R}^{2}$} \\
\hline & & F Hitung & $\mathrm{Sig}$ & t Hitung & Sig & \\
\hline (Constant) & 4,510 & \multirow{3}{*}{35,230} & \multirow{3}{*}{0,000} & 3,371 & 0,001 & \multirow{3}{*}{0,409} \\
\hline Kualitas Pelayanan $\left(\mathrm{X}_{1}\right)$ & 0,192 & & & 8,247 & 0,000 & \\
\hline Kepuasan (X2) & 0,211 & & & 3,064 & 0,000 & \\
\hline
\end{tabular}

a. dependent variable : Niat Berkunjung Kembali

Sumber: Hasil pengolahan data penelitian 2015

Pengujian hipotesis (H1) menghasilkan nilai signifikansi jalur pengaruh langsung kualitas pelayanan terhadap niat berkunjung kembali dengan nilai 0,000 (Kurang dari nilai alpha 0,05 ) dan nilai $t_{\text {hitung }} 8,247$ dengan nilai koefisien standardized sebesar 0,753 . Hasil ini memberikan arti bahwa, jika kualitas pelayanan yang diberikan baik maka semakin meningkat nilai dari niat berkunjung kembali wisatawan mancanegara yang datang. Dengan demikian hipotesis pertama dapat diterima.

Pengujian hipotesis (H2) menghasilkan nilai $\mathrm{t}_{\text {hitung }}$ 3,064 dengan nilai signifikansi 0,000 (kurang dari nilai alpha 0,05) dengan koefisien standardized sebesar 0,280. Hasil ini menunjukkan bahwa kualitas pelayanan berpengaruh positif dan signifikan terhadap niat berkunjung kembali wisatawan yang datang ke Daya Tarik Wisata Alas Pala Sangeh. Semakin besar kepuasan yang diterima oleh wisatawan maka, semakin besar pula kemungkinan wisatawan dalam melakukan kunjungan kembali

Pengujian hipotesis ketiga (H3) dilakukan menggunakan F-test (simultan) yang akan menunjukkan apakah kualitas pelayanan dan kepuasan yang dimasukkan dalam model mempunyai pengaruh secara bersamaan terhadap niat berkunjung kembali wisatawan.

Pengujian hipotesis (H3) menghasilkan nilai signifikansi 0,000 (kurang dari nilai alpha 0,05 ) dengan $F_{\text {hitung }}$ sebesar 35,230 (diatas $F_{\text {tabel }}$ 3,94 ). Hasil ini menunjukkan penghitungan dalam regresi ini dapat digunakan memprediksi secara bersama-sama pengaruh kualitas pelayanan dan kepuasan terhadap niat berkunjung kembali wisatawan mancanegara

\section{Analisis Korelasi}

Analisis korelasi digunakan untuk mengetahui kekuatan hubungan variabel $\mathrm{X}$ dengan variabel $Y$. Berdasarkan hasil pengolahan SPSS dapat dilihat nilai $R$ adalah 0,649 hal ini menunjukkan bahwa variabel kualitas pelayanan, kepuasan, serta niat berkunjung kembali memiliki korelasi yang kuat. 


\section{Analisis Koefisien Determinasi}

Analisis ini digunakan untuk mengetahui sejauh mana variasi variabel kualitas pelayanan dan kepuasan terhadap variabel niat berkunjung kembali wisatawan di Daya Tarik Alas Pala Sangeh.

Nilai $R$ Square sebesar 0,421 maka nilai koefisien determinasi adalah $\mathrm{D}=0,421 \mathrm{x}$ $100 \%=42 \%$. Koefisien determinasi sebesar $42 \%$ menunjukkan bahwa variabel bebas yang meliputi kualitas pelayanan (X1) dan kepuasan (X2) berpengaruh terhadap variabel niat berkunjung kembali (Y) sebesar $42 \%$.

Berdasarkan data analisis yang telah diperoleh, wisatawan yang mengunjungi Daya Tarik Wisata Alas Pala Sangeh lebih banyak berjenis kelamin laki-laki dengan usia 31-40 tahun, dengan benua asal wisatawan adalah Eropa dan lebih banyak merupakan wisatawan yang baru pertama kali melakukan kunjungan ke Daya Tarik Wisata Alas Pala Sangeh.

\section{Pengaruh Kualitas Pelayanan terhadap Niat Berkunjung Kembali Wisatawan Mancanegara ke Daya Tarik Wisata Alas Pala Sangeh \\ Pada Hasil pengujian hipotesis pertama} menunjukkan, kualitas pelayanan berpengaruh dan signifikan terhadap niat berkunjung kembali wisatawan di Daya Tarik Wisata Alas Pala Sangeh. Hasil pengujian menunjukkan bahwa nilai koefisien sebesar 0,192 dan signifikansi sebesar 0,000 menunjukkan adanya pengaruh kualitas pelayanan terhadap niat berkunjung kembali wisatawan secara tidak langsung.

Kualitas pelayanan merupakan salah satu indikator yang penting dapat menarik semakin banyak wisatawan untuk melakukan kunjungan ulang. Dengan keadaan dilapangan dimana wisatawan yang sangat senang akan kualitas pelayanan yang diberikan oleh ranger atau staff, yang tidak di dapat di daya tarik wisata sejenis.

\section{Pengaruh Kepuasan terhadap Niat Berkunjung Kembali Wisatawan Mancanegara ke Daya Tarik Wisata Alas Pala Sangeh \\ Pada pengujian hipotesis kedua} menunjukkan bahwa kepuasan berpengaruh positif dan signifikan terhadap niat berkunjung kembali wisatawan ke Daya Tarik Wisata Alas Pala Sangeh. Hasil pengujian menunjukkan bahwa nilai koefisien adalah 0,211 dan signifikansi sebesar 0,000 menunjukkan bahwa kepuasan berpengaruh positif dan signifikan terhadap niat berkunjung kembali wisatawan ke Daya Tarik Wisata Alas Pala Sangeh.

Wisatawan yang datang mengunjungi secara keseluruhan sangat puas akan keadaan daya tarik wisata ini dan ingin mengunjungi kembali tempat ini dikemudian hari, dan tidak pindah ke daya tarik wisata sejenis yang ada.

Pengaruh Kualitas Pelayanan dan Kepuasan terhadap Niat Berkunjung Kembali Wisatawan Mancanegara ke Daya Tarik Wisata Alas Pala Sangeh

Pada hasil hipotesis ketiga menunjukkan bahwa, kualitas pelayanan dan kepuasan secara bersama-sama berpengaruh positif dan signifikan terhadap niat berkunjung kembali wisatawan. Hal ini dapat ditunjukkan dengan hasil pengujian secara simultan bahwa nilai $\mathrm{F}$ hitung 35,230 lebih besar dibanding $\mathrm{F}$ tabel dengan signifikansi 0,000 yang menunjukkan tingkat signifikansi kurang dari 0,005 dengan ini dapat ditarik kesimpulan bahwa kualitas pelayanan serta kepuasan secara bersamasama mempengaruhi niat berkunjung kembali wisatawan ke Daya Tarik Wisata Alas Pala Sangeh.

Dalam penelitian ini kualitas pelayanan dan kepuasan hanya mencakup berpengaruh $42 \%$ dari niat berkunjung kembali, dan $58 \%$ lagi dapat dipengaruhi faktor lain yang tidak diteliti dalam penelitian yang penulis lakukan.

Untuk hubungan antara variabel kualitas pelayanan dan kepuasan terhadap niat berkunjung kembali, diperoleh hasil nilai $R$ sebesar 0,649, dengan ini dapat dimasukkan pada kategori hubungan yang kuat.

\section{SIMPULAN DAN SARAN Simpulan}

Hasil Dari penelitian dapat ditarik sebuah kesimpulan, yaitu :

1. Kualitas pelayanan berpengaruh positif dan signifikan terhadap niat berkunjung kembali wisatawan. Semakin baik kualitas pelayanan yang diberikan pada wisatawan oleh ranger di Daya Tarik Wisata Alas Pala Sangeh, maka semakin besar niat berkunjung kembali wisatawan.

2. Kepuasan berpengaruh signifikan terhadap niat berkunjung kembali wisatawan. Dengan terciptanya kepuasan maka akan 
mendorong niat berkunjung kembali wisatawan yang semakin besar.

3. Kualitas pelayanan dan kepuasan secara bersamaan berpengaruh signifikan terhadap niat berkunjung kembali wisatawan mancanegara. Semakin baik kualitas pelayanan yang diberikan dan semakin positif kepuasan yang diterima langsung saat melakukan perjalanan wisata maka semakin kuat niat berkunjung kembali Wisatawan Mancanegara

\section{Saran}

Atas hasil penelitian ini, dapat diajukan beberapa saran sebagai berikut :

1. Pihak pengelola perlu meningkatkan kebersihan fasilitas toilet dan pendukung lain seperti jalan setapak, serta perlu meningkatan perhatian dan kepedulian, terhadap wisatawan dengan tidak membedakan wisatawan berdasarkan negara asal wisatawan.

2. Pengelola perlu memberikan informasi yang jelas dalam penanganan keluhan yang dirasakan wisatawan serta pengelola harus giat dalam mengikuti trand perkembangan pariwisata yang ada.

3. Penelitian ini hanya sebatas pada Wisatawan Mancanegara saja, sebaiknya selanjutnya dapat meneliti mengenai wisatawan domestik dandapat menambahkan variabel citra destinasi pariwisata.

\section{DAFTAR PUSTAKA}

Baker, D. A. and Crompton, J. L. 2000. Quality, satisfaction and behavioral intentions. Annals of Tourism Research, Vol 27(3), 785-804.

Mat Som, Achmad Puad., Marzuki, Azizan., Yousefi, Maryan., \& AbuKhalifeh, Ala'a Nimer. 2012. “ Factor Influencing Visitors Revisit Behavioral Intentions : A Case Study of Sabah, Malaysia“ International Journal of Marketing Studies. Published by Canadiancenter of Science and Education. vol. 4 No. 4 ;2012.

Oliver, Richard L. 1980. "A Cognitive Model of the Antecedents and Consequences of Satisfaction Decisions ", Journal of Marketing Research, Published by: American Marketing Association, Vol. 17, No. 4 ; Nov., 1980, pp. 460-469.

Oom de Vallue, Patricia., Silva, Julio Albino., Mendes, Julio., Guerreioro, Manuela. 2006. " Tourist Satisfaction and Destination Loyalty Intention : A Structural and Categorical Analysis " International Journal of Business Science and Applied Management, Vol 1, Issue 1, 2006.

Parasuraman, Zeithamel, Valarie. A \& Berry, Leonard. L. 1988. "A Multiple-Item Scale For Measuring Consumer Perceptions Of Service Quality". International Journal of Service Quality, Vol. 64 No 1. 